OSKAR EAPETA

UNIWERSYTET WARSZAWSKI

\title{
ZJAWISKO MUZYCZNYCH IDÉES FIXES W TWÓRCZOŚCI KOMPOZYTORSKIEJ EUGENIUSZA MORAWSKIEGO: W POSZUKIWANIU GENEZY I INTERPRETACJI
}

\begin{abstract}
7 godnie ze słownikową definicją terminem idée fixe określamy natrętną myśl prześladującą chronicznie daną osobę, której intensywność i obsesyjność staje się niemal patologiczna ${ }^{\mathrm{I}}$. Elementy spełniające te kryteria odnaleźć można w twórczości wielu kompozytorów, a idées fixes przejawiają się w różnorodny sposób: czasem będzie to użycie charakterystycznego motywu lub tematu muzycznego, czasem nawiązanie do określonej tematyki w warstwie programowej. Przykładem najbardziej znanym jest Symfonia fantastyczna i Lélio Hectora Berlioza, w których powtarzający się temat symbolizujący ukochaną bohatera określony został przez samego kompozytora właśnie tym mianem. Dmitrij Szostakowicz używał niemieckiej transliteracji swoich inicjałów do stworzenia czterodźwiękowego motywu-kryptogramu $\mathrm{DEsCH}$, który wprowadzał do swoich licznych utworów. Idée fixe fińskiego kompozytora Einojuhaniego Rautavaary była z kolei topika anielska, powracająca w wielu jego dziełach i związana z zastosowaniem konkretnych technik kompozytorskich. Artysta chętnie komentował swoje „kompozycje anielskie”, wskazując na różnorakie źródła inspiracji - koszmarne wizje śnione w dzieciństwie, Elegie duinejskie Rainera Marii Rilkego, archetyp cienia obecny w psychologii Carla Gustava Junga czy wreszcie biblijny motyw walki Jakuba z aniołem ${ }^{2}$. Zarówno temat Berlioza, jak też motyw Szostakowicza i topika anielska w kompozycjach Rautavaary powracają wielokrotnie, stanowią rodzaj motta, z którego twórcy chętnie korzystali, aby podkreślić szczególnie dla nich ważne elementy dzieł i nadać im charakter po części autobiograficzny.
\end{abstract}

I Zob. np.: https://www.merriam-webster.com/dictionary/id\%C3\%Age\%2ofixe, dostęp 9 XII 2018.

2 Zob.: Wojciech Stępień, Signifying angels. Analyses and interpretations of Rautavaara's instrumental compositions, Helsinki 2010 (= Studia Musicologica Universitatis Helsingiensis 20), s. 266-267. 
Prowadzone przeze mnie badania nad twórczością Eugeniusza Morawskiego (I876-1948) pozwolity wyodrębnić dwie idées fixes. Z zastanawiającą regularnością powracają one w ważnych semantycznie miejscach w kompozycjach programowych tego twórcy. Znaczna część spuścizny Morawskiego zaginęła w czasie ostatniej wojny ${ }^{3}$, dlatego też z konieczności wnioski formułowane w niniejszym artykule dotyczą jego nielicznych ocalałych kompozycji. Proponuję przyjrzenie się tym dziełom przez pryzmat dwóch wspomnianych wyżej myśli muzycznych, które wydają się istotne dla zrozumienia intencji przyświecających kompozytorowi. Elementy te zostały już co prawda zauważone przez dwóch badaczy, jednakże żaden z nich nie odniósł ich do całości spuścizny kompozytorskiej Morawskiego ${ }^{4}$.

Pierwsza idée fixe pojawiła się w koncepcji twórczej Morawskiego wcześnie, bo już w 1902 roku. Jego najbliższy przyjaciel, litewski malarz i kompozytor Mikalojus Konstantinas Čiurlionis, przebywał wówczas w Lipsku na stypendium ufundowanym przez księcia Michała Mikołaja Ogińskiego. Artyści prowadzili ze sobą korespondencję - intensywną ze strony osamotnionego w nowym środowisku Litwina i niezbyt częstą ze strony nie lubiącego pisać listów Morawskiego. W jednym z nich pojawia się jednak motyw, który powracać będzie w wielu późniejszych kompozycjach. List ten, datowany na I3 i I4 V 1902 r., otwiera, bez żadnego wstępu, zadedykowane Zofii Sierzputowskiej Preludium C-dur, jedna z bardzo niewielu zachowanych kompozycji fortepianowych Morawskiegos. Zaraz po nim kompozytor wpisał do listu fragment nutowy opatrzony znamiennym komentarzem ${ }^{6}$ :

3 Pełny wykaz zaginionych kompozycji Morawski podał w liście do Związku Kompozytorów Polskich w grudniu 1946 roku. Obejmuje on m.in. pięć oper, trzy poematy symfoniczne, cztery symfonie, jedno oratorium, trzy koncerty instrumentalne, trzy balety, dziesięć sonat, siedem kwartetów i muzykę sceniczną do dwóch sztuk, zob.: Archiwum Związku Kompozytorów Polskich, teczka „Eugeniusz Morawski”, bez sygn.

4 Zob.: Radosław Okulicz-Kozaryn, „Dzwony. Zaczynając od listu Eugeniusza Morawskiego do Mikalojusa Konstantinasa Čiurlionisa”, w: Mikalojusa Konstantinas Čiurlionis, litewski malarz i kompozytor, red. Elżbieta Giszter, Katowice 2006, s. I23-I40, a także: Marcin Gmys, Harmonie i dysonanse. Muzyka Mtodej Polski wobec innych sztuk, Poznań 20I2, rozdz. „Młodopolskie dzwony”, s. 419-429.

5 Drugim zachowanym dziełem przeznaczonym na ten instrument jest pochodzące z tego samego okresu Finale fis-moll na cztery ręce, będące ostatnią częścią zaginionej sonaty.

6 List ten cytuje zarówno Radosław Okulicz-Kozaryn, jak i Marcin Gmys. Wszystkie przykłady muzyczne pojawiające się w niniejszym tekście zostały opracowane przez autora. 


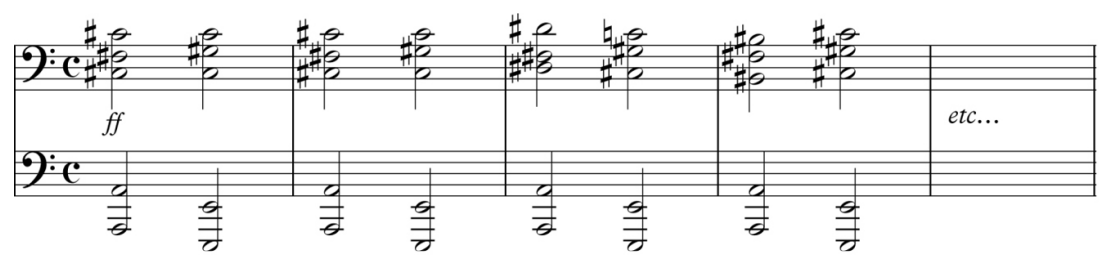

Jest to podstawa harmoniczna, na tle której mam zamiar napisać pochód na cmentarz z dzwonami. Czy te akordy (odpowiednio instrumentowane) mogą imitować dzwony [?]. Naturalnie to jest tylko formuła harmoniczna. Można później zmieniać tonacje, rytm etc. etc. Chodzi o to, że dzwony nigdzie nie są użyte ffff, tylko zawsze $p$ lub najwyżej $f$. W owym pochodzie na cmentarz ja zrobię tak, że doprowadzę dzwony do niemożliwego wprost rozbujania się. Będzie takie bicie w dzwony, jakby cały świat chowali. Otóż, zdaje mi się, taką siłę mają tylko te duże sekstowe akordy; właśnie wpadłem na dwa:

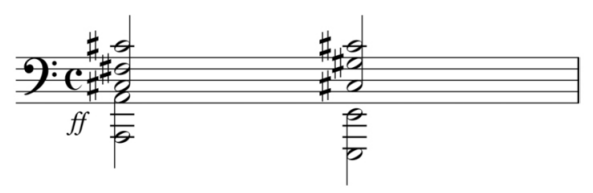

Zagraj je kilkanaście razy fortissimo. Lepiej by może brzmiały o parę tonów niżej, ale na fortepianie źle brzmią, bo niskie nuty są u mnie rozstrojone. Napisz mi o tej formule szczerze ${ }^{7}$.

Ów motyw dzwonów, jak można go nazwać, jest w oryginalnej postaci kadencją plagalną w tonacji cis-moll w pierwszym przewrocie, ze zdwojoną oktawowo tercją akordu w rejestrze basowym. Użycie kadencji plagalnej w kontekście pogrzebowym wskazuje również na konotacje religijne. Wszak właśnie przejście z czwartego na pierwszy stopień skali używane było często, aby zaakcentować słowo „amen” w śpiewach liturgicznych. Swoisty fatalizm konstatacji kojarzonej powszechnie ze słowami „niech tak będzie” wzmaga jeszcze opadający o kwartę w dół kształt tego motywu, niosący skojarzenia z westchnieniem. Tym samym więc, zgodnie z przemyśleniami Constantina Florosa, można potraktować motyw dzwonów jako jeden z symboli muzycznych, czyli intencjonalnie wprowadzaną przez kompozytora mikrostrukturę, której celem jest nadanie odcinkowi dzieła treści pojęciowej, co wpływa na interpretację hermeneutyczną całej kompozycji ${ }^{8}$. Čiurlionis odpisał przyjacielowi 8 czerwca. Odniósł się z entuzjazmem do jego pomysłu, porównał go też z imitacją brzmienia dzwonów w operze Die versunkene Glocke Heinricha Zöllnera, kompozytora który uczył wówczas kompozycji w lipskim konserwatorium: muzyki, red. Ludwik Bielawski, Katarzyna Dadak-Kozicka, Warszawa I998, s. 79-95. 
Twoje Dzwony, chociaż b. proste, brzmią dziwnie ponuro i silnie. To ciągłe w równym rytmie cis robi wrażenie czegoś nieubłaganego, a te „a”, „e”, „a”, „e” w basie i lamentuje, i wyrwać się chce, i rozwalić to cis, ale nie może. Cis brzmi ciągle wielkie, nieubłagane i słuchając zdaje się, że ono nie miało nigdy początku i nigdy brzmieć nie przestanie. Robi się straszno i „a”, „e” tym okropniej jęczy. Dzwony będą świetne, tylko sęk w instrumentacji, jak źle zinstrumentujesz, to wszystko na nic. Słyszałem dzwon w Dzwonie zatopionym Zöllnera.

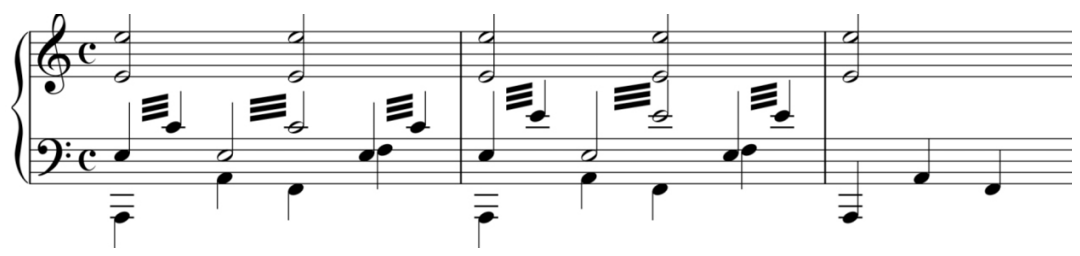

Formuła, jak widzisz, nie taka dobra jak Twoja, ale brzmi wspaniale, bo jest dobrze zinstrumentowana. Niestety nie zauważyłem szczegółów, wiem tylko że chór, który ciągnie półnutami 3 różne „e” robi ten wspaniały efekt.

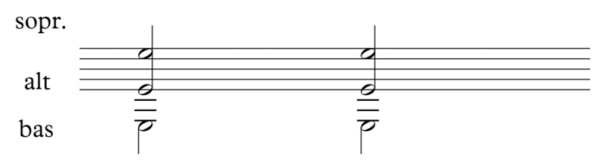

Nie słychać śpiewu ani głosów, tylko $2 y \pi^{9}$, instrumenty pomagają i wychodzi byczo ${ }^{10}$.

Topos dzwonów był na przełomie XIX i XX w. elementem w zasadzie wszechobecnym - zarówno w muzyce, jak i w literaturze i sztukach plastycznych. Spotykamy go w twórczości ulubionego poety Morawskiego, Edgara Allana Poego ${ }^{\mathrm{II}}$, a także we wchodzącym w skład zbioru Kwiaty zta wierszu Spleen Charles'a Baudelaire'a. Ok. 1906 r. Morawski napisał symfonię programową opartą na tym dziele (dziś zaginiona), jeśli więc nawiązał do tego wiersza, to jest wysoce prawdopodobne, że i tam użył swego ulubionego motywu. Dzwony występują także w niezliczonych dziełach poetów Młodej Polski, wliczając w to utwory Kazimierza Przerwy-Tetmajera, Leopolda Staffa czy Antoniego Langego. Symbol ten miał tak silne konotacje funeralne, że Bolesław Leśmian pisał w wierszu Tarcza wręcz o „dzwonnej śmierci” " było w sztukach plastycznych, gdzie w tym właśnie kontekście temat ten podjął m.in. Čiurlionis w Symfonii pogrzebowej (1903), Trwodze (1904) czy w Sonacie stonecznej, będącej finałem Sonaty I (1907). Być może dzieła te powstały jako dalekie echo korespondencji z najbliższym przyjacielem.

9 Z rosyjskiego: huk, zgiełk, łoskot.

IO List z 8 VI 1902 r., zach. Nacionalinis M.K. Čiurlionio dailès muziejus w Kownie, sygn. $\mathrm{Cl}_{38}$.

II Zob. wiersze Dzwony, Pieśń o dzwonach; nic jednak nie wskazuje na to, aby Morawski kiedykolwiek zainspirował się jakimś konkretnym wierszem Poego.

I2 Zob.: R. Okulicz-Kozaryn, op. cit., s. I3O. 
Również w muzyce topos dzwonów w XIX w. powracał w zasadzie bezustannie. Dzwony odzywają się w kompozycjach Hectora Berlioza, Gustava Mahlera, Modesta Musorgskiego, Richarda Wagnera czy Siergieja Rachmaninowa. Często symbolizowano też dzwon pogrzebowy uderzeniem tam-tamu - dzieje się tak w Adagio lamentoso w VI Symfonii Piotra Czajkowskiego i w poemacie symfonicznym Śmierć i wyzwolenie Richarda Straussa, a w usta Muzy w I akcie Wyzwolenia Wyspiański wkłada poniższą kwestię:

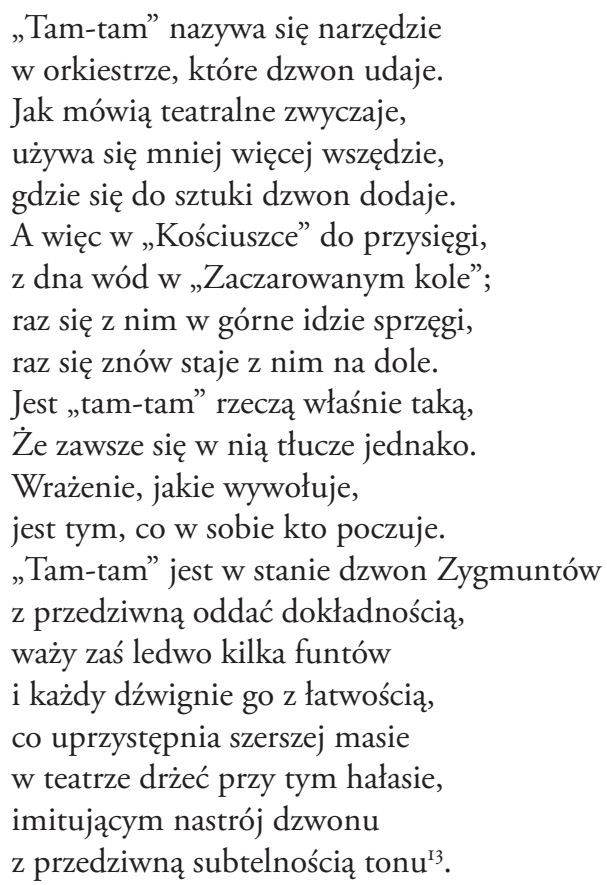

Pierwszym zachowanym dziełem Morawskiego, w którym pojawia się motyw dzwonów, jest skomponowany około I9II r. i zadedykowany zaprzyjaźnionej z kompozytorem malarce i lalkarce Frydzie Frankowskiej poemat symfoniczny Nevermore. Dzieło to oparte jest na wierszu Edgara Allana Poego Kruk (The Raven). Jako tytuł kompozycji Morawski wykorzystał słowo, które powtarza tytułowy ptak w odpowiedzi na pytania podmiotu lirycznego dotyczące możliwości odzyskania przez niego zmarłej ukochanej, Lenory. Powtarzające się systematycznie przeczące odpowiedzi kruka, odpowiadającego „nevermore” na każde zadane mu pytanie, doprowadzają bohatera do granic obłędu. Tęsknota i żal z powodu śmierci ukochanej kobiety są toposem par excellence romantycznym. Jak pisał Poe w Filozofi kompozycji:

I3 Stanisław Wyspiański, Wyzwolenie, Gdańsk 2000, s. I4-I5. 
[...] śmierć pięknej kobiety jest niewątpliwie najbardziej poetycznym tematem świata, i tak samo nie ulega wątpliwości, że temat ten brzmi najlepiej w ustach człowieka, który stracił ukochaną istotę ${ }^{\mathrm{I} 4}$.

Słowa te współgrają również z poglądami Marii Janion, dotyczącymi żałoby i utraty:

Cała polska nowożytna wrażliwość skupia się na melancholijnych obrządkach wokół wyobrażonych kobiecych zwłok, które stają się czczoną relikwią i tworzywem pamiątek ${ }^{15}$.

Swój poemat symfoniczny zbudował Morawski z trzech tematów. Pierwszy z nich, prezentowany przez pierwszy fagot i kontrabasy w oktawach w tempie Largo i w dynamice $p p \mathrm{z}$ oznaczeniem espressivo, określany jest w literaturze jako temat nieukojonej tęsknoty ${ }^{16}$. Silnie schromatyzowany, wykorzystuje interwał kwinty jako element konstrukcyjny, co nadaje mu gotycyzującego, surowego i poważnego charakteru. Temat ten wykorzystuje dwanaście dźwięków skali chromatycznej, co może mieć w tym wypadku podwójne znaczenie. Prezentowany jest w formie czterogłosowego fugata, a ponieważ polifonia była odczytywana jako symbol mądrości - Morawski nawiązuje tutaj do fugi z poematu symfonicznego Richarda Straussa Tako rzecze Zaratustra (część $O$ wiedzy), której temat także oparty jest na takim samym materiale ${ }^{\mathrm{I} 7}$. Drugim źródłem inspiracji mogła być natomiast Symfonia faustowska Ferenca Liszta. Pierwszą część tego dzieła pt. Faust otwiera dwunastodźwiękowy, atonalny temat oddający zagubienie i brak punktu oparcia dla myśli protagonisty. Morawski mógł znać ten utwór, wykonany w Filharmonii Warszawskiej w I903 roku. Pierwszy temat Nevermore wydaje się więc być kombinacją tych dwóch elementów - polifonia symbolizuje mądrość, a chromatyka i brak centrum tonalnego symbolizują zagubienie, niepokój, brak stabilności i oparcia dla myśli.

Kontrastuje z tą myślą powierzony rożkowi angielskiemu diatoniczny temat drugi wprowadzony w tempie Lento z oznaczeniem molto espressivo (przykł. I). Zbudowany jest on na dźwiękach skali e-moll eolskiej. Określany jest w literaturze mianem tematu Lenory ${ }^{18}$, jednakże ze względu na jego rolę w dziełach Morawskiego wypada określić go mianem bardziej ogólnym: tematu śmierci kobiety. Funeralne skojarzenia wywoływane przez ten temat podkreśla zastosowanie altowej odmiany oboju. Instrument ten był niejednokrotnie wykorzystywany przez kompozytorów do reprezentowania melancholii i żałoby, a za sztandarowy przykład może posłużyć Łabędź z Tuoneli z suity Lemminkäinen op. 22 Jeana Sibeliusa.

I4 Edgar Allan Poe, „Filozofia kompozycji”, Przeglad Humanistyczny I6 (I972) nr 5, s. 39, cyt. za: M. Gmys, op. cit., s. 175.

I5 Maria Janion, Niesamowita stowiańszczyzna, Kraków 2006, s. 274.

I6 M. Gmys, op. cit., s. I78.

17 Ibid.

I8 Ibid. 


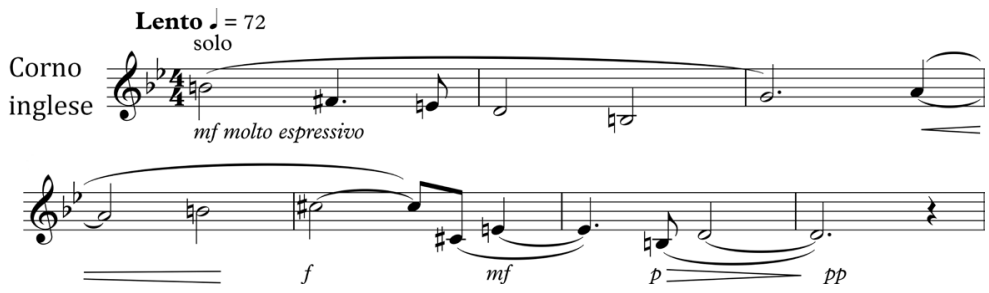

Przykł. I. Eugeniusz Morawski, Nevermore, temat drugi, nr 5, t. I-7.

Temat trzeci w tempie Andante cantabile w tonacji $C$-dur wprowadzany jest przez grające unisono trzy flety. Określany jest jako temat nadziei na odzyskanie zmarłej Lenory ${ }^{19}$. O tym, jak od samego początku złudna jest ta nadzieja, świadczy motyw dzwonów kontrapunktujący tę myśl niczym upiorne memento mori. Zaprezentowany został przez Morawskiego w dynamice $p p$ przez najniższe instrumenty dęte blaszane - grające con sordini trzy puzony i tubę. Dobór tonacji nie jest przypadkowy i prowadzi do rozbicia narracji na dwie warstwy. Tonacja $C$-dur reprezentuje miłość i nadzieję, a akordy f-molli $c$-moll-nieodwracalną śmierć i odczuwaną przez bohatera żałobę. Temat nadziei powtórzony zostaje następnie sekwencyjnie przez waltornię, a tę repetycję również domyka motyw dzwonów, tym razem pojawiający się pod postacią akordów c-moll i g-moll (przykł. 2).

Myśl ta powraca również w kulminacji wyrazowej całego dzieła, w sekcji oznaczonej Maestoso. Fragment ten, przedstawiający moment konfrontacji podmiotu lirycznego z faktem nieodwołalności śmierci Lenory, Morawski oparł na temacie trzecim. Zaprezentowany jest on jednak tym razem niemal jako marsz żałobny - grają go fortissimo possibile puzony w tonacji $b$-moll, a towarzyszy mu wykonywane tutti przez resztę orkiestry ostinato, które wydaje się być wręcz ilustracyjną reprezentacją słów wiersza, w których bohater desperacko próbuje odgonić raniącego go wciąż kruka: „Zdejm mi z serca dziób twój ptasi, co jak ostry razi nóż” ${ }^{20}$. Nagromadzone napięcie prowadzi do kulminacji opartej na motywie dzwonów (akordy es-moll i b-moll), dociążanej jeszcze semantycznie uderzeniami symbolizującego żałobny dzwon tam-tamu ${ }^{2 \mathrm{I}}$. Moment ten obrazuje utratę przez bohatera wszelkich złudzeń i powrót do emocjonalnego punktu wyjścia, co kompozytor obrazuje powrotem tematu pierwszego. Co prawda motyw dzwonów nie pojawia się w dziele Morawskiego z taką regularnością jak słowo „nevermore” w wierszu Poego, ale fakt jego wystąpienia w tak ważnych z dramaturgicznego punktu widzenia miejscach poematu skłania do refleksji, że być może jest on muzycznym ekwiwalentem tego słowa.

O W oryginale fragment ten brzmi: „Take thy beak from out my heart, and take thy form from off my door!”. Cytuję fragment tłumaczenia Barbary Beaupré, które Morawski mógł znać, zob. polskie przekłady wiersza The Raven na stronie http://home.agh.edu.pl/ szymon/raven.shtml, dostęp Io XII 2018.

$2 \mathrm{I}$ 

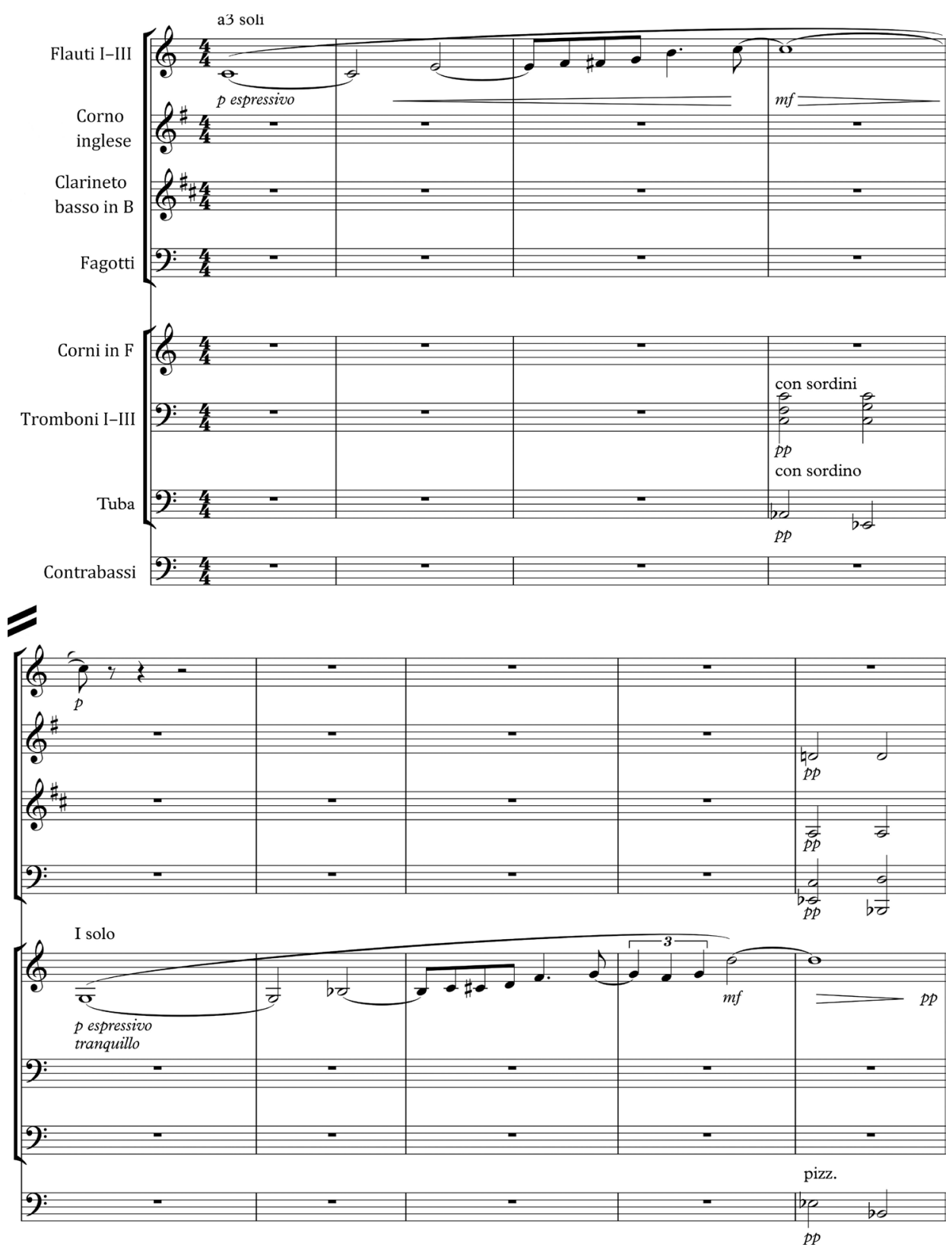

Przykł. 2. Eugeniusz Morawski, Nevermore, temat trzeci z motywem dzwonów pod postacią kadencji plagalnej w c-moll i w $g$-moll, nr I7 i i8. 
Kolejnym dziełem Morawskiego, w którym pojawia się jego muzyczna idée fixe, jest późniejszy o kilka lat poemat symfoniczny Ulalume, również oparty na wierszu Poego. Jego tematyka jest bliźniaczo podobna do treści Kruka. Mężczyzna, znajdujący się późną jesienią w lesie Weir nad jeziorem Auber, prowadzi dialog ze swoją duszą (określaną mianem Psyche). Podąża za zwodniczym światłem gwiazdy Astarte, by ostatecznie dotrzeć pod koniec wędrówki do grobu ukochanej Ulalume i uświadomić sobie jej stratę. W autografie Ulalume Morawski umieścił całość wiersza Poego we francuskim przekładzie Stéphane’a Mallarmégo. Związek pomiędzy wierszem a opartym na jego kanwie poematem jest dość ścisły, chociaż Morawski nie podążał niewolniczo za literackim pierwowzorem. Zdarzało mu się zmieniać kolejność zdań, czasem zaś nową myśl muzyczną wprowadzał w środku strofy. Dzieło otwiera potężna ekspozycja prezentująca trzy główne tematy, część centralną zajmuje czwarty temat wraz z czterema jego wariacjami, po nich zaś następuje repryza - narzucona kompozytorowi przez Poego - symbol powrotu bohatera do punktu wyjścia.

Temat pierwszy zaprezentowany jest w tempie Largo. Nazywany jest w literaturze tematem narratora ${ }^{22}$ lub tematem spopielałego serca ${ }^{23}$. Otwiera go tremolo drugich skrzypiec na dźwięku $d^{I}$, który jest następnie obsesyjnie powtarzany w różnych wartościach rytmicznych. Błądzenie narratora po nawiedzonym lesie Weir oddane jest przez czterogłosowe, silnie schromatyzowane fugato. Kluczowy element tego odcinka pojawia się po raz pierwszy już w czwartym i szóstym takcie dzieła. Są to akordy g-moll i $d$-moll, które tworzą znaną już kadencję plagalną w pierwszym przewrocie. Zaprezentowana została zresztą przez te same instrumenty co w Nevermore - przez grające $p p$ i $m p$ trzy puzony i tubę (przykł. 3). Motyw dzwonów powraca też kilkanaście taktów dalej w tej samej szacie orkiestrowej (akordy des-moll i as-moll), w momencie powtarzania głównego tematu przez pierwsze skrzypce. Rola tej kadencji wydaje się służyć takiemu samemu celowi co w Nevermore - poprzez dyskretną i nienarzucającą się w odbiorze słuchowym szatę dźwiękowym sygnalizuje na wstępie, że strata jest już faktem dokonanym, który jednak pozostaje poza zasięgiem świadomości podmiotu lirycznego.

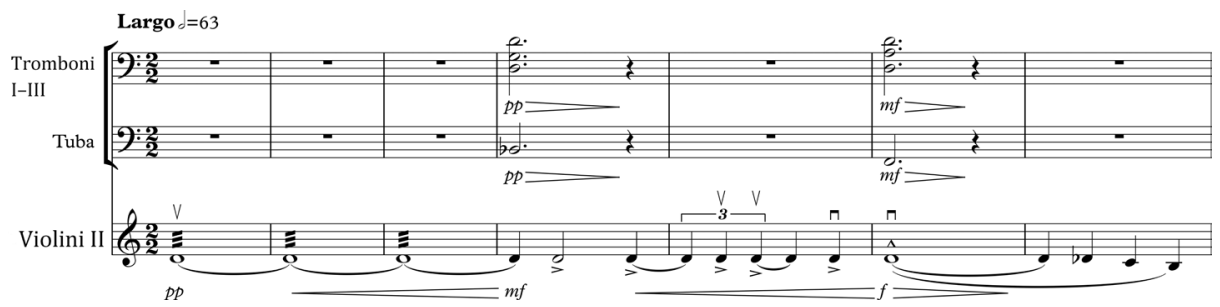

Przykł. 3. Eugeniusz Morawski, Ulalume, temat pierwszy i motyw dzwonów pod postacią akordów g-moll i $d$-moll, t. I-7.

22 Zofia Helman, Między romantyzmem a nowa muzyka, Warszawa 2013, s. I89.

23 M. Gmys, op. cit., s. I83. 
Temat drugi wprowadza fagot, który przekazuje go następnie sekwencyjnie altówkom, a te ulubionemu przez Morawskiego rożkowi angielskiemu. Przez badaczy nazywany jest tematem Ulalume ${ }^{24}$ bądź tematem Psyche ${ }^{25}$. Zgodnie z relacją brata kompozytora, Włodzimierza Morawskiego, artysta wykorzystał w tym miejscu materiał tematyczny zaginionej pieśni Rondel de l'adieu (incipit to „Partir c'est mourir”) do słów Edmonda Haraucourta ${ }^{26}$. Temat trzeci określany jest zgodnie przez komentatorów mianem tematu Astarte. Fenicka bogini płodności, młodopolski symbol fatalnej zmysłowości, przedstawiana jest niekiedy jako kobieca postać z rogami. Całkiem trafnie więc Morawski zdecydował się powierzyć tę myśl brzmiącym w dwugłosie waltorniom.

Ostatni z tematów tego dzieła - temat Ulalume ${ }^{27}$ bądź temat mężczyzny ${ }^{28}$ - prezentowany jest w tempie Adagio przez flet solo na tle granych arpeggio w dynamice pianissimo akordów dwóch harf. Pierwszy z tych akordów to motyw dzwonów, prezentowany ponownie za pomocą akordów $g$-moll i $d$-moll (przykł. 4). Funkcjonuje tutaj - podobnie jak w poprzednich przypadkach - jako subtelne memento mori, uzmysławiające bohaterowi beznadziejność jego starań i sankcjonując nazwanie tego tematu imieniem tytułowej bohaterki.

Powraca ono w subtelny sposób na początku drugiej wariacji pod postacią akordów as-moll i es-moll, w chwili, w której czwarty temat pojawia się w partii skrzypiec solo. Motyw dzwonów ponownie rozbrzmiewa wtedy również w partii pierwszej harfy. W wymowny sposób myśl ta powróci jeszcze dwukrotnie w momencie uzmysłowienia sobie przez protagonistę śmierci ukochanej. Bohater znajduje się tutaj, podobnie jak w adekwatnym miejscu wiersza Kruk, w emocjonalnym punkcie wyjścia. Gdy powraca temat pierwszy, Morawski wpisał do partytury fragment Ulalume, który w przekładzie Barbary Beaupré brzmi następująco:

Serce me spopielało w proch szary,

Jako liści uwiędłych plon suchy,

Jako liści zmartwiałych plon suchy ${ }^{29}$.

Motyw dzwonów pojawia się w tym miejscu partytury dwukrotnie - najpierw jako akordy $g$-moll i $d$-moll, potem zaś jako akordy $d$-moll i a-moll.

Dwuczęściowy balet Świtezianka powstał najprawdopodobniej ok. 1922 roku. Stylistyka tego dzieła jest kompletnie odmienna od poematów symfonicznych Morawskiego wykazujących jeszcze wpływy neoromantyczne. W warstwie muzycznej

24 Ibid

25 Z. Helman, op. cit.

26 Józefa Kołek, Pieśni solowe Eugeniusza Morawskiego, Uniwersytet Warszawski 1964 (niepublikowana praca magisterska), s. 6. Również w tym wierszu pojawia się motyw rozstania i utraty.

27 Zob.: Z. Helman, op. cit.

28 Zob.: M. Gmys, op. cit.

29 Edgar Allan Poe, Kruk. Wybór poezyi, Kraków I9ı. 


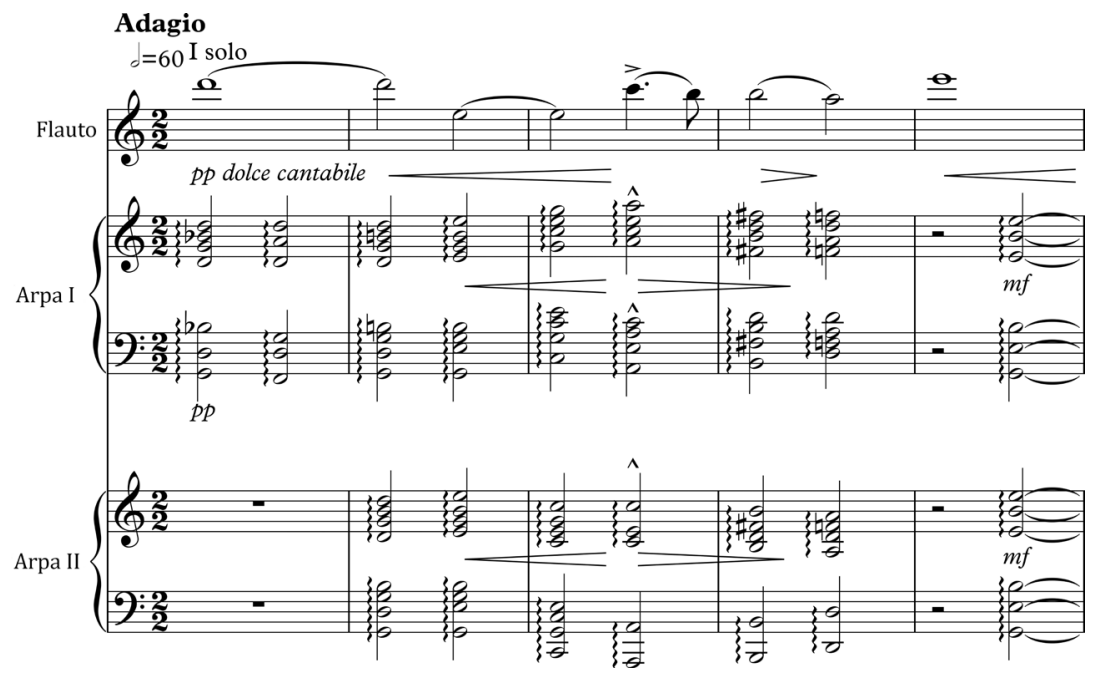

Przykł. 4. Eugeniusz Morawski, Ulalume, temat czwarty. Motyw dzwonów pod postacią kadencji $\mathrm{w} d$-moll w partii pierwszej harfy w pierwszym takcie, nr 23, t. 9-IO, oraz nr 24, t. I-3.

jest to kompozycja przynależąca do XX w., w której można odnaleźć wpływy twórczości baletowej Igora Strawińskiego, Siergieja Prokofiewa czy Maurice’a Ravela. Fabuła Świtezianki wprowadza tematykę pradawnej pogańskiej słowiańszczyzny z elementami dziewiętnastowiecznej powieści gotyckiej. Morawski eksponuje w muzyce ostrą i wyrazistą rytmikę, a także korzysta z zapożyczonej od kompozytorów rosyjskich techniki ostinata. Pomimo tytułu przywodzącego skojarzenia z balladą Adama Mickiewicza, autorem libretta tego dzieła jest kompozytor. Jest to historia trójkąta miłosnego, rozgrywającego się pomiędzy bohaterami zamieszkującymi osadę nad jeziorem Świteź. Młoda sierota Sagna kocha z wzajemnością drwala Wita. O jej względy zabiega kneź Ryś, dziewczyna jednak odrzuca jego zaloty. W akcie zemsty rycerz razem z drużyną napada na wioskę podczas obchodów Nocy Kupały i uprowadza rywala. Zrozpaczona Sagna zostaje sama nad brzegiem jeziora, a kiedy z mgieł wyłaniają się starające się ją pocieszyć ondyny, nimfy i rusałki, dziewczyna ulega ich namowom i podąża do jeziora, gdzie topi się, stając się tytułową Świtezianką. Ryś nadal jednak pragnie Sagny dla siebie, przyprowadza więc związanego rywala nad jezioro i każe mu przywabić zjawę dziewczyny grą na klarnecie. Kiedy ta pojawia się we mgłach, pachołkowie Rysia zabijają drwala, a kneź w jego przebraniu spieszy na spotkanie Sagny. Ta jednak wciąga go coraz głębiej w odmęty, aż rycerz traci grunt pod nogami i tonie, a rusałki i ondyny cieszą się z dokonanej na nim zemsty. Tematyka baletu jest uniwersalna - dotyczy pożądania, zbrodni i zemsty. Toposem romantycznym jest samobójcza śmierć głównej bohaterki dzieła, która po śmierci staje się postacią bytującą na granicy dwóch światów. Jak pisze Maria Janion: 
Można powiedzieć, że romantycy żyją w stanie szaleństwa pochodzącego od nie opuszczających ich zmarłych. Wyobraźnię romantyczną nawiedzają - zgodnie z ,antropologią wsi polskiej” - zwłaszcza widma i trupy tych, wobec których nie dokonano stosownego rytuału przejścia, tych, którzy zostali dotknięci nagłą i nienaturalną śmiercią, śmiercią nieoswojoną - samobójcy, rażeni piorunem, zamordowani ${ }^{30}$.

Taką postacią jest właśnie Sagna, będąca w drugiej części baletu wodnicą, w którą obsesyjnie zapatrzony jest Ryś, co w końcu i jego doprowadza do zguby. Wszyscy bohaterowie dzieła charakteryzowani są motywami przewodnimi, które towarzyszą każdorazowo ich pojawieniu się na scenie w tej samej szacie instrumentacyjnej. Instrumentem reprezentującym Rysia jest trąbka, Wita - klarnet w stroju Es, Sagna zaś reprezentowana jest przez akordowy temat zasygnalizowany zaraz na początku baletu i prowadzony politonalnie w dwóch niezależnych planach harmonicznych. Pojawienie się tej myśli poprzedza czterotaktowa introdukcja, w której grająca solo waltornia cytuje temat drugi z poematu Nevermore, tym razem przeniesiony przez Morawskiego do tonacji a-moll (przykł. 5). To niezwykle wymowny gest, zapowiedź przyszłych tragicznych wydarzeń i symbol nieodległej w czasie śmierci głównej bohaterki.

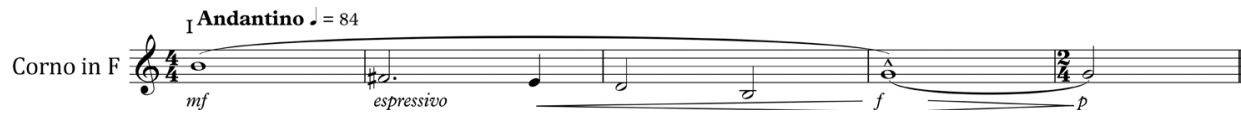

Przykł. 5. Eugeniusz Morawski, Świtezianka, cytat z poematu Nevermore, t. I-5.

Dokładny przebieg akcji baletu możliwy był do odtworzenia dzięki uwagom zapisanym przez kompozytora w szczęśliwie zachowanym autografie Świtezianki, określającym, co dzieje się w danym momencie dzieła ${ }^{31}$. Pod koniec pierwszej części, w momencie, w którym zbiry Rysia wyprowadzają szamoczącego się Wita, Morawski zapisał: „Sagna wyciąga ręce ku niebu”, a gestowi temu towarzyszy powtórzony pięciokrotnie motyw dzwonów, tym razem pod postacią akordów h-moll i fis-moll. Pierwsze dwa powtórzenia zaprezentowane są tutti $\mathrm{w}$ dynamice fortissimo possibile, a każdemu z akordów towarzyszy uderzenie tam-tamu. Dwie następne repetycje pojawiają się $\mathrm{w}$ piano $\mathrm{w}$ zmniejszonej obsadzie, a ostatnie pojawienie się tej myśli $\mathrm{w}$ pianissimo w składzie zredukowanym do fagotu, sarusofonu, waltorni i fortepianu rozdzielają wymowne pauzy. W następnym odcinku baletu „Sagna tańczy swą rozpacz”, a niedługo potem pojawiają się zjawy, które „tańczą i wabią Sagnę ku sobie” ${ }^{2}$, a ta rzuca się do wody i topi się.

30 M. Janion, op. cit., s. 80.

3I Autograf Świtezianki zach. w Bibliotece Narodowej, sygn. Mus. I228, sygn. mf. 23926.

32 Ibid. 
Czteroczęściowy poemat taneczny Mitość to najbardziej rozbudowany z zachowanych utworów Morawskiego. Dzieło powstało w 1. I925-28, a autorem libretta był malarz, grafik, scenograf i krytyk sztuki Franciszek Siedlecki. Scenariusz ten zachował się na marginesach wyciągów fortepianowych dzieła ${ }^{33}$. Kompozycja powstała jako reakcja na tragiczne wydarzenia I wojny światowej. W zamierzeniu autorów dzieło miało być monumentalnym, trwającym około trzech godzin widowiskiem, które przedstawia alegoryczną wędrówkę pary głównych bohaterów, Młodzieńca i Dziewicy, od świata maszyn, przez sferę planet, świat wiecznej miłości aż po ziemię, gdzie protagoniści odnaleźć mieli upragnione szczęście. W dziele tym pojawiają się, podobnie jak w Świteziance, konsekwentnie przeprowadzone motywy przewodnie symbolizujące postacie lub pojęcia.

Część pierwsza złożona jest z dziewięciu scen. Rozgrywa się w świecie maszyn, symbolizujących tu siłę destrukcyjną, wrogą naturze i ludzkości. Przedstawiające maszyny postacie zapraszają do tańca grupy ludzi, których następnie przykuwają do wielkiej machiny w Tańcu maszyn. Po zakończeniu tego odcinka na scenie pojawiają się główni bohaterowie wykonujący Taniec Młodzieńca i Dziewicy. W odróżnieniu od pozostałych ludzi, nie dają się wciągnąć w grę maszyn. Ich decyzji nie zmienia nawet pojawienie się Króla Maszyn, grożącego bohaterom śmiercią, którą może zadać za pomocą elektryczności. Władca wzywa więc do pomocy alegoryczne postacie Pychy i Mocy. Wykonują one taniec, w którym udaje im się oczarować parę głównych bohaterów. Wtedy wysuwają się złote kraty. Siedlecki pisze w tym miejscu w wyciągu fortepianowym „Młodzi widzą się uwięzieni” 34 . Rozpoczyna się scena VI, której centralnym elementem jest pieśń śpiewającego za sceną chóru:

Na całe życie schwytani w krąg, służyć będziecie siłom.

Dusze się wasze nie wyrwą stąd w słońca ożywcze promienie!

Spojonych ruchem zębatych kół z wieczną maszyną,

Świata już nie opuści rozpacz i ból, jeno ze śmiercią zbrata ${ }^{35}$.

Odcinek ten rozpoczyna się w tempie Lento i praktycznie w całości oparty jest na motywie dzwonów, który przyjmuje tutaj postać kadencji plagalnej w tonacji gis-moll (akordy cis-moll i gis-moll) i symbolizuje sytuację grozy, opresji i zagrażającej śmierci. Wprowadzają go pesante grające w ciemnym kolorycie altówki, wiolonczele, kontrabasy, fagoty, klarnet basowy i klarnety A. W takcie trzecim motyw przejmują organy, które akompaniują chórowi, wykonując tę kadencję przez cały pierwszy wers. Po jego zakończeniu instrumenty dęte blaszane wprowadzają trwającą dwa takty myśl

33 Autografy partytur i wyciągów fortepianowych Mitości znajdują się w posiadaniu bratanka kompozytora, Tomasza Morawskiego, i to z tych egzemplarzy korzystał autor, przygotowując niniejszy artykuł. Zmikrofilmowane wersje dostępne są w Bibliotece Narodowej w Warszawie pod sygnaturami mf. III24-III27. Fotokopie partytur Mitości i Świtezianki dostępne są również w katalogu Polskiego Wydawnictwa Muzycznego.

34 Archiwum rodziny Morawskich, bez sygnatury.

35 Ibid. 
poboczną o opadającej linii melodycznej, po której motyw dzwonów przejmowany jest przez wokalizujący chór na tle tremolo altówek (przykł. 6). Po dwóch taktach kadencję przejmują znowu organy, akompaniując chórowi podczas wykonywania drugiego wersu. Po jego zakończeniu motyw pojawia się w partii grających pizzicato smyczków, po czym znów przejmują go organy. W zakończeniu tego odcinka myśl pojawia się ponownie w partii wokalizującego chóru, a akcja płynnie przechodzi w scenę VII, gdzie motyw powtarza się jeszcze na przestrzeni trzech taktów. Ogółem kompozytor repetuje opisany motyw w tym ustępie baletu aż trzydzieści dwa razy.

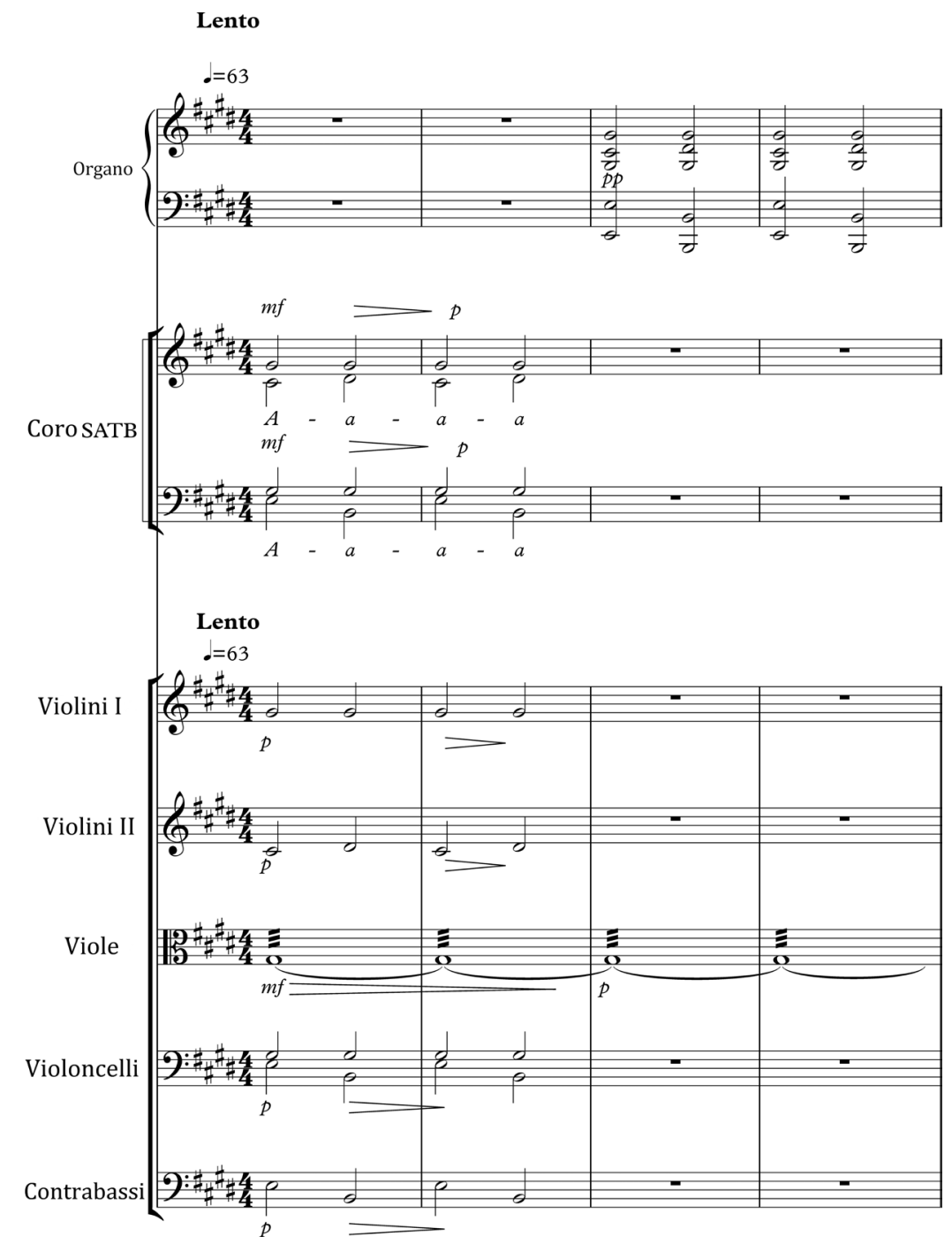

Przykł. 6. Eugeniusz Morawski, Mitość, cz. I, motyw dzwonów pod postacią kadencji w tonacji gis-moll, nr 4I, t. 8-IO, $\mathrm{nr} 42$, t. I. 
Młodzieniec i Dziewica bezskutecznie próbują uwolnić się z potrzasku, a kiedy zdają sobie sprawę z beznadziejności swojego położenia, postanawiają popełnić samobójstwo przez naciśnięcie przycisku w elektrycznej machinie, którą wcześniej wskazywał im Król Maszyn. Tańczą oparty na motywie opadającej tercji Taniec mitości i śmierci, który wypełnia całą scenę VIII. Kolejna scena opisana została przez Siedleckiego następująco:

Wchodzą na platformę maszyny śmiercionośnej. Dają sobie ostatnie pocałowanie. Młodzieniec już ma przycisnąć łącznik, lecz nagle słychać głuchy grzmot... a z głębi wychyla się jasna postać Anioła Stróża. Zatrzymał rękę młodzieńca. Usypia ich wzrokiem - a potem otwiera im oczy, ażeby we śnie widzieli i wyprowadza na srebrny krąg, na którym się zjawił ${ }^{36}$.

W momencie, w którym bohater ma uruchomić śmiercionośną maszynerię, odzywa się powtórzony trzykrotnie motyw dzwonów, przechodzący od fortissimo possibile do pianissimo. Jego prezentacja odbywa się przy udziale całej orkiestry, łącznie z organami, a złowrogi charakter sceny podkreślają uderzenia tam-tamu. Motyw przyjmuje tym razem, podobnie jak w kulminacji Nevermore, postać kadencji w funeralnej tonacji $b$-moll (akordy es-moll i $b$-moll). Pojawienie się obrońcy pary anonsowane jest zaś przez oktawowe zawołania w partii trąbki (od $c^{2}$ do $c^{3}$ ) i temat Anioła Stróża, prezentowany w jaskrawych barwach instrumentalnych (frullato fletów, tremolo czelesty i skrzypiec) na dźwiękach skali całotonowej. Chór za sceną wzywa Młodzieńca i Dziewicę do dalszej wędrówki, po czym „Srebrny krąg unosi się z wolna w górę a jasna postać gaśnie..." 37 . Na tym kończy się pierwszy obraz baletu.

Ostatnim pod względem chronologicznym zachowanym dziełem Morawskiego wykorzystującym idée fixe jest muzyka sceniczna do sztuki Lilla Weneda Juliusza Słowackiego napisana ok. I930 r. ${ }^{38}$. W katalogu dzieł kompozytora figurowała również zaginiona opera pod tym tytułem, możliwe więc, że Morawski wykorzystał w muzyce scenicznej motywy zaczerpnięte z tego dzieła ${ }^{39}$. Muzyka sceniczna do Lilli Wenedy składa się z wyciągu fortepianowego Prologu, chórów dwunastu harfiarzy wieńczących akty od pierwszego do czwartego ${ }^{40}$, a także z siedmiu dodatków do aktu pierwszego i drugiego. Obsada dzieła składa się z instrumentów dętych drewnianych (obój, rożek angielski, dwa klarnety B, klarnet A, saksofon barytonowy Es, saksofon tenorowy B), pojedynczych instrumentów dętych blaszanych (waltornia F, trąbka B, trąbka C, puzon, tuba), perkusji (kotły, tam-tam,

36 Ibid.

37 Ibid.

38 Autograf zach. w Bibliotece Narodowej w Warszawie, sygn. Mus. 97.

39 Zob.: list Eugeniusza Morawskiego do Związku Kompozytorów Polskich z grudnia 1946 r. zawierający listę strat wojennych, zach. Archiwum ZKP, op. cit.

40 Chóry te zachowały się zarówno w formie pełnej partytury, jak też wyciągu fortepianowego. 
talerze, trójkąt, werbel, wielki bęben), fortepianu, harfy, kwintetu smyczkowego oraz wokalistów - sopranu solo i chóru basów. Muzyka sceniczna Morawskiego do Lilli Wenedy nie była nigdy wykonywana, nie istnieje też żadna jej rejestracja fonograficzna. Treścią dramatu Słowackiego jest zagłada rodu Wenedów, pobitych przez Lechitów. Nieuchronnie zbliżającą się tragedię przeczuwa siostra tytułowej bohaterki, Roza Weneda, rozmawiając w Prologu z siostrą i Harfiarzami. Aby zasugerować ciążące nad rodem fatum, Morawski po raz kolejny posłużył się motywem dzwonów. Pojawia się on już w trzecim takcie wykonywanego przed podniesieniem kurtyny Prologu jako grane fortissimo possibile akordy as -moll i es-moll, poprzedzone granym crescendo i tremolo dźwiękiem es (przykł. 7). To wymowny gest, podobnie jak w przypadku Ulalume zaprezentowany już na samym wstępie kompozycji, służy za motto i symbol nieuchronnej klęski.

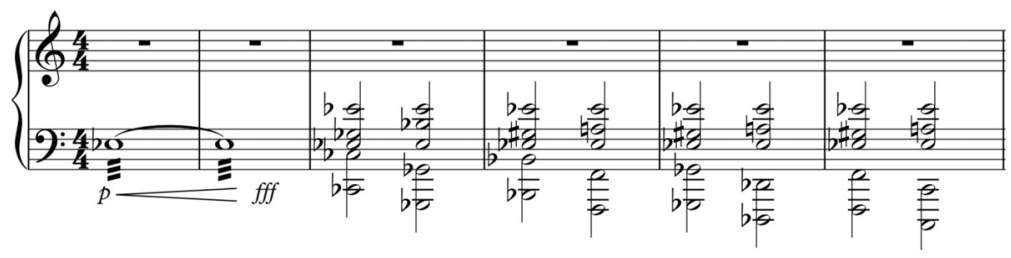

Przykł. 7. Eugeniusz Morawski, muzyka sceniczna do Lilli Wenedy, akt III, t. I-6, motyw dzwonów pod postacią akordów as-moll i es-moll.

Kadencja ta powraca od razu w Prologu, towarzysząc rozmowie sióstr. Dodatkowo pojawia się w partii harfy pod postacią granych ad libitum akordów es-moll i b-moll w momencie, w którym Słowacki zapisał „słychać dźwięk harfy”, co Roza Weneda komentuje następująco:

$\mathrm{O}$ ! Cyt, harfy nasze grają.

Słyszysz ich głosy ponure,

Płaczące i rozstrojone?

Harfiarze wchodzą na górę...

Wszystko stracone! ${ }^{11}$

Po raz wtóry myśl ta powraca w tym samym odcinku dzieła, w kolejnym dodatku, kiedy Roza mówi:

Ogień, nim we łzach ostygnie,

Dwanaście ludów podźwignie;

Za trzy dni wszystkiemu kres,

Walka i zgon! ${ }^{42}$.

4I Juliusz Słowacki, Lilla Weneda, Gdańsk 200o, s. 8.

42 Ibid., s. I3. 
Po słowach tych następuje sześciokrotne powtórzenie w tempie Lento kadencji b-moll, którą Harfiarze komentują następująco:

Nasze harfy tobie w ton

Odgrały smutnie ${ }^{43}$.

Cztery Chóry Harfiarzy zamykają akt pierwszy, drugi, trzeci i czwarty dramatu, stanowią ich podsumowanie i rekapitulację najważniejszych wątków. W akcie pierwszym Harfiarze wzywają Wenedów do boju i zagrzewają ich do walki:

A kiedy milczy niebo - śpiewa chór.

A kiedy śpiewa chór - drży serce wroga! ${ }^{14}$

Oba wersy rozdzielone są dwukrotnym pojawieniem się motywu dzwonów w dynamice forte w partiach wszystkich instrumentów. Pierwszy powrót tej kadencji to znane już doskonale akordy es-moll i $b$-moll, za drugim razem jednak Morawski jedyny raz prezentuje tę myśl w tonacji durowej, jako akordy $E s$-dur i $D$-dur. Kontrast pomiędzy trybami w tym miejscu dzieła wprowadza na moment element płonnej nadziei.

W akcie drugim synowie króla Wenedów Derwida, Lelum i Polelum, za zgodą króla Lecha, podejmują się próby oswobodzenia się z niewoli. Mają z odległości stu kroków rzucić toporem tak, aby odciąć włos z głowy przywiązanego do drzewa króla Derwida, ich ojca. Wydarzenia te chór komentuje słowami:

Niestety! niestety!

Gdzie sprawiedliwość boska? Gdzie pioruny?45

Kwestię tę antycypuje czterokrotnie powtórzona tutti pianissimo kadencja w tonacji es-moll (przykł. 8), symbolizująca tym razem bardziej niepokój związany z próbą, niż antycypacją tragedii - braciom udaje się bowiem celnie rzucić toporem.

43 Ibid.

44 Ibid., s. 29.

45 Ibid., s. 45 . 


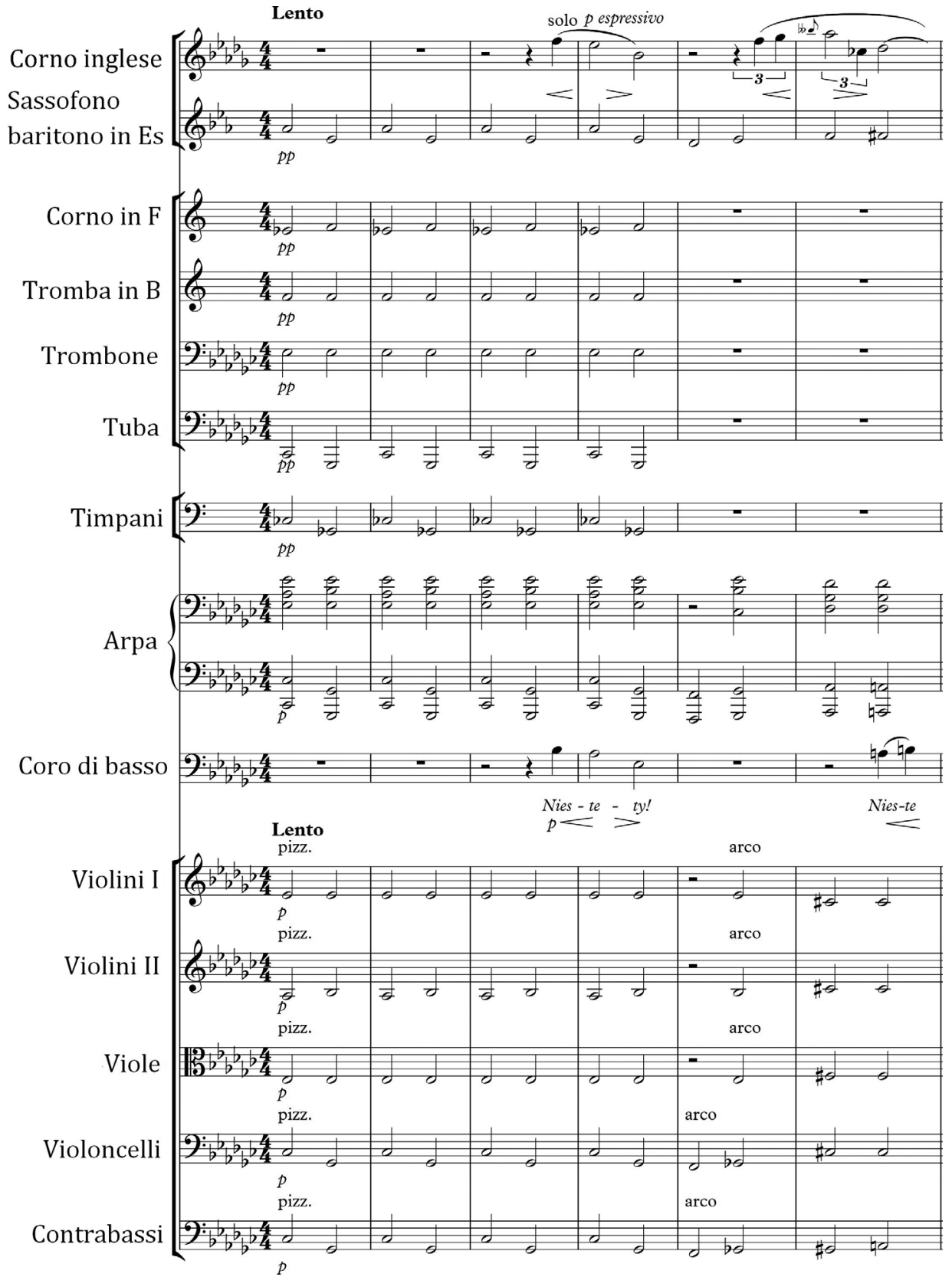

Przykł. 8. Eugeniusz Morawski, muzyka sceniczna do Lilli Wenedy, akt II, t. I-6, motyw dzwonów pod postacią powtórzonej czterokrotnie kadencji w tonacji es-moll. 
Podsumowanie czwartego aktu w wykonaniu Harfiarzy to przede wszystkim skarga nad wyrzeczeniami, których trzeba do zwycięstwa, zaś w warstwie muzycznej wyraźna zapowiedź tragicznych wydarzeń, które rozegrają się już w akcie piątym. $\mathrm{Na}$ początku tego ogniwa saksofon barytonowy wprowadza w tonacji es-moll temat śmierci kobiety (przejęty następnie sekwencyjnie przez obój), a towarzyszy mu obsesyjnie powtarzany przez kotły i grające pizzicato smyczki dźwięk es. Kulminuje on zresztą w wymowny sposób w takcie czwartym uderzeniem symbolizującego śmierć tam-tamu. Pojawienie się tego tematu akurat w tym miejscu antycypuje tragiczny zgon tytułowej bohaterki na początku następnego aktu. W zakończeniu tego ogniwa raz jeszcze powraca motyw dzwonów, tym razem ponownie pod postacią powtórzonych czterokrotnie akordów b-moll i es-moll, przechodzących od mezzoforte do pianissimo.

Zarówno temat zapożyczony z poematu Nevermore, jak też pochodzący z wczesnego listu do Čiurlionisa motyw dzwonów stanowią emblematy stylu kompozytorskiego Morawskiego. Obsesyjnie powracają w kompozycjach należących do różnych gatunków i pisanych w różnych okresach życia kompozytora. Morawski, identycznie jak Hans Pfitzner w operze Palestrina, wykorzystał do zasugerowania obecności dzwonów środki harmoniczne. Jego kadencja jest czasami połączona z wykorzystaniem tam-tamu w miejscach o szczególnym napięciu (kulminacje w Nevermore, Świteziance i w Mitości), występuje jednak również w cichej dynamice w charakterze prezentowanego sotto voce akompaniamentu (Nevermore, Ulalume). Motyw ten spaja ze sobą postromantyczne poematy symfoniczne z późnymi baletami i z muzyką do Lilli Wenedy. Jest stałym elementem języka muzycznego Morawskiego, występuje przy tym przecież w miejscach, w których - wyjąwszy list do Čiurlionisa - nie ma mowy o dzwonach. Można zatem przyjąć, że motyw ten występuje w jego dziełach na zasadzie „niewyśpiewanego symbolu” (unsung symbol). W żadnym z zachowanych źródeł kompozytor ani słowem nie wspomina o użyciu tego motywu w swoich kompozycjach. Można jednak przyjąć, że miał on dla niego ogromne, a przy tym niemal intymne znaczenie. Być może wiązał się z jakąś wczesną i traumatyczną stratą, o której do tej pory nic nie wiemy, być może był tylko wyrazem fascynacji młodopolską konwencją. Pewną wskazówką może być tonacja, w której Morawski po raz pierwszy zaprezentował ten motyw przyjacielowi. W tonacji cis-moll utrzymana jest Sonata fortepianowa op. 27 nr 2 Ludwiga van Beethovena, zwana powszechnie Sonata księżycowa i kojarzona z niespełnionym uczuciem kompozytora do Giulietty Guicciardi, jednej z najpoważniejszych kandydatek do miana Unsterbliche Geliebte. Argument ten wzmacnia fakt, że opowiadający o utraconej miłości poemat symfoniczny Ulalume kończy się potężnym wyładowaniem dynamicznym w tej samej tonacji, jak też to, że dzieło, wraz z Nevermore, podejmuje temat utraty. Najsilniejszą inspirację do poruszenia pewnych wątków stanowią osobiste doświadczenia autorów. Obsesyjne powracanie Morawskiego do motywu śmierci ukochanej kobiety może mieć w tym 
przypadku takie same źródło. Nie bez znaczenia jest tu także kontekst poezji Młodej Polski, w którym strata, śmierć, żal i melancholia pojawiały się bardzo często. Dobrym punktem odniesienia są też tematy podejmowane w poematach symfonicznych pisanych przez urodzonego w tym samym roku co Morawski Mieczysława Karłowicza. Materia dzieł takich jak Powracajace fale, Stanistaw i Anna Oświecimowie czy Smutna opowieś́ jest bliźniaczo podobna do tej podjętej w poematach Morawskiego, a autor Ulalume nie był też obojętny na poezję młodopolską, o czym świadczą jego zachowane pieśni do tekstów Leopolda Staffa (traktująca o utraconej miłości La détresse) czy Tadeusza Micińskiego (Las płaczacych brzóz), a także liryki do słów poetów francuskich - za przykład może posłużyć Un grand sommeil noir do słów Paula Verlaine’a, a także wspomniana już, zaginiona pieśń według wiersza Haraucourta. Być może podjęta przez Morawskiego topika dzwonów pozostawała też w nie do końca uświadomionej relacji do œuvre Fryderyka Chopina. Słowa Kazimierza Korda, komentujące twórczość autora Poloneza-fantazji, można więc odnieść również do Eugeniusza Morawskiego:

Dzwon może o wszystkim opowiedzieć. Nie tylko o początku dnia czy nabożeństwa, ale też o narodzeniu i śmierci, o nadziei, o rozstaniu, oczekiwaniu i przywiązaniu. Rozbrzmiewając rozkołysany, wszystko pamięta i zapisuje. [...] Dzwony szczególnie kochają Chopina i często u niego rozbrzmiewają, pomimo że ich nie ma. Widocznie Chopin wszędzie je słyszał. Tajemnicą ich dźwięku jest bezgraniczna siła, którą ludzie intuicyjnie wiążą z opowiadaniem o nieskończoności. Bo przecież - brzmienie dzwonu nigdy się nie kończy, ono zawsze trwa ${ }^{46}$.

\section{THE PHENOMENON OF MUSICAL IDÉES FIXES IN EUGENIUSZ MORAWSKI'S COMPOSITION WORKS: IN SEARCH OF GENESIS AND INTERPRETATION}

The article deals with compositions by Eugeniusz Morawski in which the composer uses one of his constantly recurring ideas, or idées fixes. The first of those ideas appears in a letter sent to his closest friend, the Lithuanian painter and composer Mikalojus Konstantinas Čiurlionis, in which Morawski describes a funeral march with the tolling of bells that are used harmonically as a plagal cadence in first inversion with the third of the triad in the bass. This bell motif was used by Morawski in almost all of his most important works, such as the symphonic poems based on verse by Edgar Allan Poe, Nevermore and Ulalume, the two ballets Świtezianka [The nymph of Lake Świteź] and Mitość [Love] and the incidental music to Juliusz Słowacki's play Lilla Weneda. In all these works, this motif occurs at moments symbolising death and oppression. Sometimes it is even more sinister, because Morawski used it as an accompaniment to themes symbolising hope. The second idée fixe might be called the theme of a woman's death. It first appears in Nevermore, where it serves as a second theme,

Kazimierz Kord, Epizody, Kraków 2019, s. I05-I06. 
played by cor anglais in E minor. It illustrates the protagonist's deceased beloved, Lenore. This theme appears for a second time at the very beginning of The nymph of Lake Switeź, where it functions as a kind of motto, anticipating the death of the main female character, Sagna. It is used with an identical purpose in the incidental music for Lilla Weneda. Both themes recur constantly in five important compositions by Morawski, written between around I9II and 1930. They seem to have had very significant meaning for the composer, although he never wrote about them. They may have represented autobiographical, intimate and obsessive symbols, so the term idée fixe is more than appropriate.

Oskar Eapeta

Słowa kluczowe / keywords: Eugeniusz Morawski, idée fixe, Ulalume, Nevermore, Świtezianka, Lilla Weneda.

Oskar Łapeta, psycholog, muzykolog i publicysta. Interesuje się muzyką XIX w. i I poł. XX wieku. W ramach muzykologicznych studiów doktoranckich w Zakładzie Powszechnej Historii Muzyki Instytutu Muzykologii UW pracuje nad dysertacją poświęconą biografii i recepcji twórczości Eugeniusza Morawskiego. Jest autorem licznych publikacji naukowych i popularnonaukowych, które ukazały się m.in. na łamach Res Facta Nova, Przeglądu Muzykologicznego, Kwartalnika Mtodych Muzykologów. Prowadzi bloga muzycznego www. klasycznaplytoteka.pl. oskar.lapeta@gmail.com

\title{
Drugi tom serii „Muzyka polska za granicą”
}

\author{
Między Warszawą a Paryżem (1918-1939) \\ red. Beata Bolestawska-Lewandowska i Jolanta Gusy-Pasiak
}

iswydawnictwo@ispan.pl 
